\title{
Parafunctional habits and their relationship with fractures of composite resin
}

\section{restorations}

Hábitos parafuncionais e sua relação com as fraturas de restaurações de resina composta

Hábitos parafuncionales y su relación con las fracturas de las restauraciones de resina compuesta

Erika Terumi Tomisaki ORCID: https://orcid.org/0000-0003-1398-8559 Universidade Estadual de Londrina, Brazil E-mail: erikaterumitomisaki@gmail.com

Matheus Bruno Costa ORCID: https://orcid.org/0000-0001-6041-9960 Universidade Estadual de Londrina, Brazil E-mail: matheusbc1009@gmail.com

Daiane Cristina Mendonça Santos Silva ORCID: https://orcid.org/0000-0003-1929-1680 Universidade Estadual de Londrina, Brazil E-mail: daiane.mendonca@hotmail.com Márcio Grama Hoeppner ORCID: https://orcid.org/0000-0001-5075-3412 Universidade Estadual de Londrina, Brazil E-mail: hoeppner@uel.br

Sueli de Almeida Cardoso ORCID: https://orcid.org/0000-0001-5238-9845 Universidade Estadual de Londrina, Brazil E-mail: suelicardoso@uel.br

\begin{abstract}
Parafunctional habits are characterized by the repetition of acts that are not related to the normal functions of the stomatognathic system. This research aims to verify the parafunctional habits practiced, perceived and reported by patients and to verify the relationship with the fractures of direct composite resin restorations. Information from 205 patients, seen at the University Dental Clinic of the State University of Londrina, was collected. After data collection, a survey and synthesis of reported parafunctional habits was performed and correlated with the fracture of composite resin restorations. The information and data were tabulated and analyzed using descriptive statistics, COUNTIF function, and the results were expressed in tables. The most frequent parafunctional habits were bruxism, followed by onychophagia, occurring in greater quantity in females. A greater number of fractured restorations were found in patients with parafunctional habits. Among the parafunctional habits verified, it was concluded that bruxism was the most frequent, related mainly to the fracture of class $\mathrm{V}$ restorations.
\end{abstract}

Keywords: Bruxism; Nail biting; Permanent dental restoration; Composite resins.

\section{Resumo}

Os hábitos parafuncionais caracterizam-se pela repetição de atos que não se relacionam às funções normais do sistema estomatognático. Esta pesquisa tem como objetivo verificar os hábitos parafuncionais praticados, perceptíveis e relatados pelos pacientes e verificar a relação com as fraturas de restaurações diretas em resina composta. Foram coletadas as informações de 205 pacientes, atendidos na Clínica Odontológica Universitária da Universidade Estadual de Londrina. Após a coleta dos dados, foi realizado o levantamento e sintetização dos hábitos parafuncionais relatados e correlacionado com a fratura de restaurações em resina composta. As informações e dados levantados foram tabulados e analisados por meio da estatística descritiva, função CONT.SE e o seus resultados expressos em formas de tabelas. Os hábitos parafuncionais mais frequentes foram o bruxismo, seguido de onicofagia, ocorrendo em maior quantidade no sexo feminino. Constatou-se maior número de restaurações fraturadas nos pacientes que possuem hábitos parafuncionais. Dentre os hábitos parafuncionais verificados, concluiu-se que o bruxismo foi o mais frequente, relacionado sobretudo com a fratura de restaurações classe V.

Palavras-chave: Bruxismo; Hábito de roer unhas; Restauração dentária permanente; Resinas compostas.

\section{Resumen}

Los hábitos parafuncionales se caracterizan por la repetición de actos que no se relacionan con las funciones normales del sistema estomatognático. Esta investigación tiene como objetivo verificar los hábitos parafuncionales practicados, 
perceptibles y relatados por los pacientes y verificar la relación con las fracturas de restauraciones directas de resina compuesta. Fueron recolectadas las informaciones de 205 pacientes atendidos en la Clínica Odontológica Universitaria de la Universidad Estatal de Londrina. Después de la recolección de datos, fue realizado el levantamiento e identificación de los hábitos parafuncionales relatados y correlacionados con los analizados por medio de estadística descriptiva, función CONT.SE y los resultados expresados en tablas. Los hábitos parafuncionales mas frecuentes fueron, el bruxismo, seguido de onicofagia, ocurriendo en mayor cantidad en el sexo femenino. Se constato un mayor número de restauraciones fracturadas en los pacientes que poseen hábitos parafuncionales. Dentro de los hábitos parafuncionales verificados, se concluyo que el bruxismo fue el mas frecuente, sobre todo relacionado con las fracturas de restauraciones clase V.

Palabras clave: Bruximo; Hábito de comerse las uñas; Restauración dental permanente; Resinas compuestas.

\section{Introduction}

The parafunction of the stomatognathic system results from the repetition of acts or functions that result in hyperactivity of the craniomandibular muscles. Activities such as bruxism, onychophagia, lip biting, chewing gum, finger sucking, as well as other bad oral habits, when exceeding the level of physio-structural tolerance of the individual, can compromise the occlusion, orofacial muscles and temporomandibular joint (Cavalcante et al., 2020; Gavish et al., 2000; Macfarlane et al., 2003). The normal intensity of the bite force ranges from 50 to $300 \mathrm{~N}$, however, this force can reach up to $1200 \mathrm{~N}$ in patients who have clenching or grinding teeth; contributing to the wear, crack or fracture of teeth and/or restorations (Hamburger et al., 2014).

Demarco et al. (2012) noted that annual failure rates between $1 \%$ and $3 \%$ can be achieved with class I and II composite resin (CR) restorations, depending on tooth type and location, operator, and socioeconomic, demographic, and behavioral elements. The authors also noted that the main reasons for failure in the long term were secondary caries, relative to the patient's risk to disease, and fracture, relative to the presence of lining material or the strength of the material used, as well as factors pertinent to the patients, such as bruxism. Opdam et al. (2014) ratified that the risk to caries disease and bruxism play a strong influence on the longevity of CR restorations in posterior teeth. Regarding cavity size, the authors pointed to a $30 \%$ to $40 \%$ increase in failure for each tooth surface involved in the restoration.

In anterior teeth, the annual failure rate of $\mathrm{CR}$ restorations ranges from 0 to $4.1 \%$, with esthetic reasons such as staining, anatomical contouring, and surface pigmentation being the main drivers of restoration replacements. Disregarding aesthetic reasons, fracture of the tooth or the restoration were the main causes of failure (Demarco et al., 2015). CR restorations in anterior teeth have more failures than those in posterior teeth, with fracture of the restoration being the main cause of failure (Smales \& Berekally, 2007).

Although CR is a versatile direct restorative material used in different clinical conditions, the restorative technique is quite sensitive. In addition to the knowledge and skill of the operator, for correct execution of the restorative protocol, the longevity of CR restorations is also dependent on the patient's collaboration, regarding the control of parafunctional habits and oral hygiene (Demarco et al., 2017; Pedrini et al., 2009). These conditions are challenges to be overcome when performing CR restorations by students in the learning phase and environment for professional training in undergraduate dental courses.

Based on this context, the aim of this study was to verify the parafunctional habits practiced, perceived and reported by patients seen at the University Dental Clinic (COU) of the State University of Londrina (UEL) and to verify the relationship with the fractures of direct restorations in $\mathrm{RC}$, regardless of the type of cavity.

\section{Methodology}

\section{Study type and ethical considerations}

This was a retrospective cross-sectional observational study that proposed to evaluate the presence and relationship of 
parafunctional habits in the longevity of direct CR restorations. The study was conducted after approval by the Ethics Committee on Research Involving Human Beings of UEL (CEP-UEL Opinion 1.607.965/2016), in the period from February 2016 to December 2018. All volunteer patients signed the Informed Consent Form.

\section{Patient selection and evaluation of restorations}

The patients were selected from a research of medical records filed in the Triage Sector of the University Dental Clinic of UEL (COU/UEL). The CR restorations were examined by two evaluators, previously calibrated dentists (Kappa = 0.87), with the aid of an exploratory probe (No. 5, Golgran, São Caetano do Sul/Brazil) and clinical mirror (No. 5, Golgran, São Caetano do Sul/Brazil), with clean, dry teeth and under direct artificial illumination, based on Ryge's fracture criteria (modified USPHS) (Ribeiro \& Pazinatto, 2016): Alpha - Restoration intact and fully retained, Bravo - Restoration partially retained with some portion of the restoration still intact (partial fracture) and Charlie - Restoration completely absent (total fracture). In the anamnesis phase, patients were asked about the presence or not of parafunctional habits, such as: bruxism, onicophagia, object biting (pen or pencil cap), unilateral chewing, chewing gum and lip/cheek biting (Melchior et al., 2012).

\section{Inclusion and exclusion criteria}

The study included patients with: direct CR restorations in anterior and posterior teeth, performed by third, fourth or fifth grade students of the UEL Dentistry course, during curricular clinical practice activities, at the COU/UEL, supervised by professors; minimum age of 18 years; the restorative procedure correctly recorded in their medical records (which year the student operator was in, date of the restoration, type of cavity according to the faces involved, restorative material used, finishing and final polishing of the restoration), and with a CR restoration with a lifetime in the oral cavity of at least 9 months, up to a maximum of 18 years (216 months).

Were excluded from the evaluation, patients with: CR restoration performed outside the COU/UEL outpatient clinics or performed by a graduated dentist, special needs, and incomplete annotations of the restorative procedure in the medical record.

\section{Data analysis}

After data collection, a survey and synthesis of the types of parafunctional habits present and correlated with the fracture of CR restorations in anterior and posterior teeth were performed. The information and data collected were tabulated and analyzed using descriptive statistics, COUNTIF function.

\section{Results}

A total of $934 \mathrm{CR}$ restorations from 205 patients were evaluated, with a mean age of $56( \pm 12.2), 136(66.3 \%)$ female and $69(33.7 \%)$ male, with a lifetime of restorations in the oral cavity from 9 months to 18 years.

From the amount of restorations evaluated (934), $366(39.1 \%)$ were placed in 83 (40.5\% of 205) patients who reported parafunctional habits, such as: bruxism 50 (60.2\%), onychophagia 23 (27.7\%), bruxism + onychophagia 3 (3.6\%), biting objects 4 (4.9\%) and unilateral chewing 3 (3.6\%). Of these patients, 54 (65.1\%) were female and $29(34.9 \%)$ were male.

According to the Ryge's criteria (modified USPHS) (Ribeiro \& Pazinatto, 2016), of the 366 restorations, 269 (73.5\%) were evaluated as intact and fully maintained restorations (Alpha), while 97 (26.5\%) with fracture of the restoration. Among the restorations evaluated with fracture, $41(42.3 \%)$ were partially retained restorations with some portion still intact (Bravo/partial fracture) and 56 (57.7\%) completely missing restorations (Charlie/total fracture). Class IV and II restorations 
were most affected by partial fracture (Bravo), while class $\mathrm{V}$ restorations were most affected by total fracture (Charlie), followed by class IV restorations (Table 1).

Table 1. Clinical evaluation of CR restorations with fracture, according to Ryge's criteria (Ribeiro \& Pazinatto, 2016).

\begin{tabular}{c|c|c}
\hline \multirow{2}{*}{$\begin{array}{c}\text { Cavity } \\
\text { Black's Classification }\end{array}$} & Criteria \\
\cline { 2 - 3 }$($ Black, 1908) & $\mathbf{N}(\%)$ & Charlie \\
Class I & $4(9.8 \%)$ & $0(0.0 \%)$ \\
\hline Class II & $13(31.7 \%)$ & $7(12.5 \%)$ \\
\hline Class III & $2(4.9 \%)$ & $3(5.4 \%)$ \\
\hline Class IV & $13(31.7 \%)$ & $17(30.4 \%)$ \\
\hline Class V & $9(22.0 \%)$ & $29(51.8 \%)$ \\
\hline Total & $41(42.3 \%)$ & $56(57.7 \%)$ \\
\hline
\end{tabular}

Source: Authors.

Quantitatively speaking, a small difference between the number of fractured restorations of anterior and posterior teeth was observed. In the anterior teeth it was noticed that the greater number of failures was in class IV restorations, while in posterior teeth class $\mathrm{V}$ restorations were the most failed (Table 2).

Table 2. Distribution of fractured restorations by region.

\begin{tabular}{|c|c|c|c|c|c|}
\hline \multirow[b]{2}{*}{ Region } & \multirow{2}{*}{$\begin{array}{c}\text { Cavity Black's } \\
\text { Classification } \\
\text { (Black, 1908) }\end{array}$} & \multicolumn{2}{|c|}{ Criteria } & \multirow{2}{*}{\multicolumn{2}{|c|}{$\begin{array}{l}\text { Total } \\
\text { N }(\%)\end{array}$}} \\
\hline & & $\begin{array}{l}\text { Bravo } \\
\text { N (\%) }\end{array}$ & $\begin{array}{c}\text { Charlie } \\
\mathbf{N}(\%)\end{array}$ & & \\
\hline \multirow{3}{*}{$\begin{array}{c}\text { Anterior } \\
\text { Teeth }\end{array}$} & Class III & $3(6.4 \%)$ & $4(8.5 \%)$ & $7(14.9 \%)$ & \multirow{3}{*}{$47(48.5 \%)$} \\
\hline & Class IV & $13(27.7 \%)$ & $16(34.0 \%)$ & $29(61.7 \%)$ & \\
\hline & Class V & $3(6.4 \%)$ & $8(17.0 \%)$ & $11(23.4 \%)$ & \\
\hline \multirow{3}{*}{$\begin{array}{c}\text { Posterior } \\
\text { Teeth }\end{array}$} & Class I & $3(6.0 \%)$ & $0(0.0 \%)$ & $3(6.0 \%)$ & \multirow{3}{*}{$50(51.5 \%)$} \\
\hline & Class II & $13(26.0 \%)$ & $6(12.0 \%)$ & $19(38.0 \%)$ & \\
\hline & Class V & $6(12.0 \%)$ & $22(44.0 \%)$ & $28(56.0 \%)$ & \\
\hline
\end{tabular}

Source: Authors.

The relationship between type of parafunctional habit and fracture criterion evidenced that Bravo and Charlie fractures were diagnosed in larger number in patients who reported bruxism, followed by those who reported onychophagia. The relationship between the type of parafunctional habit and cavity evidenced that bruxism resulted in a higher percentage of Bravo fracture for class II and IV cavities, followed by class V cavity. Whereas, for Charlie fractures, a higher percentage of failure occurred for class $\mathrm{V}$ restorations due to bruxism and onychophagia, followed by class IV restorations (Table 3). 
Table 3. Evaluation of parafunctional habit and the type of fracture (Ribeiro \& Pazinatto, 2016), according to the cavity.

\begin{tabular}{|c|c|c|c|c|c|c|}
\hline & \multicolumn{6}{|c|}{ Criterion Bravo } \\
\hline $\begin{array}{c}\text { Parafunctional } \\
\text { habit }\end{array}$ & $\begin{array}{l}\text { Class I } \\
\mathbf{N}(\%)\end{array}$ & $\begin{array}{l}\text { Class II } \\
\mathbf{N}(\%)\end{array}$ & $\begin{array}{c}\text { Class III } \\
\mathbf{N}(\%)\end{array}$ & $\begin{array}{c}\text { Class IV } \\
\mathbf{N}(\%)\end{array}$ & $\begin{array}{l}\text { Class V } \\
\mathbf{N}(\%)\end{array}$ & $\begin{array}{l}\text { Total } \\
\text { N }(\%)\end{array}$ \\
\hline Bruxism & $1(3.8 \%)$ & $8(30.8 \%)$ & $2(7.7 \%)$ & $8(30.8 \%)$ & $7(26.9 \%)$ & $26(100 \%)$ \\
\hline $\begin{array}{c}\text { Bruxism + } \\
\text { onychophagia }\end{array}$ & - & - & - & - & $1(100 \%)$ & $1(100 \%)$ \\
\hline Biting objects & $1(100 \%)$ & - & - & - & - & $1(100 \%)$ \\
\hline \multirow[t]{2}{*}{ Onychophagia } & $2(15.3 \%)$ & $5(38.5 \%)$ & - & $5(38.5 \%)$ & $1(7.7 \%)$ & $13(100 \%)$ \\
\hline & \multicolumn{6}{|c|}{ Criterion Charlie } \\
\hline $\begin{array}{c}\text { Parafunctional } \\
\text { habit }\end{array}$ & $\begin{array}{l}\text { Class I } \\
\mathbf{N}(\%)\end{array}$ & $\begin{array}{l}\text { Class II } \\
\mathbf{N}(\%)\end{array}$ & $\begin{array}{c}\text { Class III } \\
\mathbf{N}(\%)\end{array}$ & $\begin{array}{c}\text { Class IV } \\
\mathbf{N}(\%)\end{array}$ & $\begin{array}{l}\text { Class V } \\
\text { N }(\%)\end{array}$ & $\begin{array}{l}\text { Total } \\
\text { N }(\%)\end{array}$ \\
\hline Bruxism & - & $3(8.9 \%)$ & $1(2.9 \%)$ & $12(35.3 \%)$ & $18(52.9 \%)$ & $34(100 \%)$ \\
\hline $\begin{array}{c}\text { Bruxism + } \\
\text { onychophagia }\end{array}$ & - & $1(50.0 \%)$ & - & - & $1(50.0 \%)$ & $2(100 \%)$ \\
\hline Biting objects & - & - & $1(50.0 \%)$ & - & $1(50.0 \%)$ & $2(100 \%)$ \\
\hline Onychophagia & - & $3(16.7 \%)$ & $1(5.5 \%)$ & $5(27.8 \%)$ & $9(50.0 \%)$ & $18(100 \%)$ \\
\hline
\end{tabular}

Source: Authors.

Of the 205 patients participating in this research, 122 reported no parafunctional habits. In these patients, $568 \mathrm{CR}$ restorations were evaluated, of which 461 (81.2\%) were intact (Alpha), 54 (9.5\%) fractured according to Bravo criterion, and $53(9.3 \%)$ Charlie criterion. The comparison between the number of patients participating in this research, without and with parafunctional habits, as well as, without and with fracture of CR restoration, indicates how strong is the influence of the presence of parafunctional habits on the longevity of the evaluated CR restorations, considering the fracture criterion (Figure $1)$.

Figure 1. Flowchart of the number of patients and CR restorations evaluated.

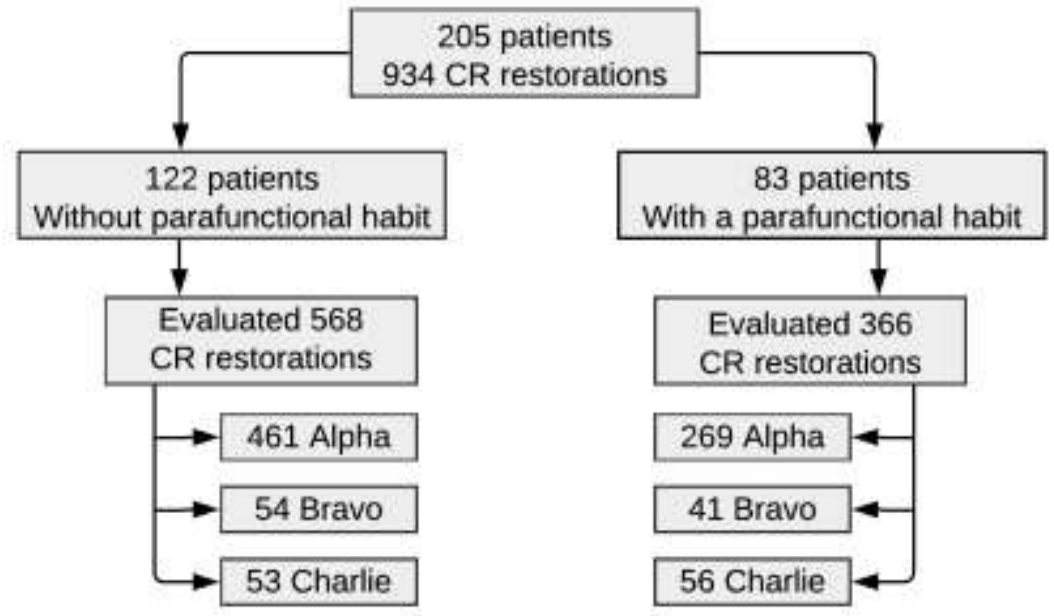




\section{Discussion}

In this study, bruxism was the most frequent parafunctional habit $(60.2 \%)$, followed by onychophagia $(27.7 \%)$. These findings ratify the study of Bortolleto et al. (2013) who observed a higher frequency for daytime and nighttime bruxism (61.0\% and $47.0 \%$, respectively), and onychophagia (37.21\%). Melchior et al. (2012), when evaluating the frequency and severity of signs and symptoms of temporomandibular disorders and the frequency of parafunctional habits, found that the most frequent parafunctional habits were: teeth clenching, teeth grinding, and chewing gum, with percentages of at least $73 \%$ of the total respondents. In turn, Almutairi et al. (2021) found as the most expressive parafunctional habits: chewing gum (86.0\%) and biting the lips or objects $(59.0 \%)$, followed by clenching the teeth and biting the nails $(45.0 \%$ and $36.0 \%$ respectively). Although the referenced articles have similar methodologies, the difference in the results is probably due to methodological limitation where, in the present study, the parafunctional habits were reported by the patients, from the questioning in the anamnesis phase.

The results showed that female patients had a higher number of parafunctional habits, which corroborates the study of Alves-Rezende et al. (2009) and Winocur et al. (2006). However, in the study by Almutairi et al. (2021), the prevalence of parafunctional habits was higher in male patients and in the younger group. While for Friedman Rubin et al. (2017) the gender and age of the patients are not significantly associated with the presence of parafunctional habits. The divergence between these studies may stem from the non-standardization of the sample regarding gender.

Among the CR restorations evaluated, the class V restorations showed a higher percentage of fractures, $51.8 \%$ total fracture and $22.0 \%$ partial fracture of the restoration, mainly related to bruxism. Namgung et al. (2013), when evaluating 564 cervical restorations, observed that 109 failed, representing $19.3 \%$ of the total, a percentage lower than that found in this study. However, the authors also observed a high percentage due to loss of retention of the restoration (82.2\%), followed by secondary caries (17.8\%). Heymann et al. (1991) suggested two probable mechanisms to justify failure of cervical restorations: lateral excursive movements, which result in a stress along the restoration-tooth interface, and large occlusal forces in centric occlusion, which cause vertical deformation of the tooth and, consequently, compression and shear at the restoration-tooth interface. Thus, we can consider that many class V restorations evaluated in this study should have been performed after careful diagnosis and treatment of possible occlusal problems. Otherwise, the restorations may be considered palliative procedures for anatomical and aesthetic restoration of cervical lesions, but not functional in terms of longevity.

Another relevant factor that may also have contributed to the failure of class $\mathrm{V}$ restorations, considering that in this study they were performed by dental students in the development and improvement phase of their clinical skills and abilities, is the isolation of the operative field. For Ichim et al. (2007), failures of class V composite resin restorations are generally attributed to inadequate moisture control during the restorative treatment.

Followed by class V restorations, the results also show that class VI restorations were the second most affected by fractures (31.7\% partial fractures and $30.4 \%$ total fractures), mainly related to onychophagia in the case of partial fractures and to bruxism in total fractures. Demarco et al. (2015) reported that class VI restorations are subjected to high masticatory load and, consequently, fracture is a possible clinical outcome over time. Therefore, the deleterious effects of masticatory force in patients with bruxism (van Dijken \& Pallesen, 2010) may have compromised the longevity of the evaluated class IV restorations.

During the activities of the masticatory system, it is desired that teeth and restorations withstand the action of axial and non-axial cyclic forces to limit potential damage such as wear or fracture. Although molar and premolar teeth have the highest bite force values compared to anterior teeth (Bakke, 2006), the presence of parafunctional habits of bruxism and 
onychophagia contributed more significantly to the fracture of class $\mathrm{V}$ and IV restorations compared to class I and II restorations.

When Laske et al. (2019) evaluated the risk factors for the failure of restorations, they concluded that the risks related to the patient, like the presence of parafunctional habits, influenced on the failure of restorations. The authors also noted that by excluding patient-related risks, the effect of operator-related risks was increased, finding a wide variation in the failure rate between operators. These findings confirm how much the diversification of the operators in the present study, students from different undergraduate series with different skill levels, may have influenced the results.

No study similar to this research was found in the literature correlating the incidence of fracture of CR restorations performed by dental students in patients with parafunctional habits. We observed that the number of fractures of the restorations was higher in the group of patients with parafunctional habits, thus we consider that further studies are necessary to evaluate their influence on the longevity of CR restorations.

\section{Final Considerations}

Based on the results obtained, it is concluded that a greater number of fractures of restorations occurred in patients with parafunctional habits, especially class V restorations, related to bruxism. The class IV restorations were the second most failed, followed by class II restorations. Class II, IV and V restorations presents a higher degree of technical difficulty, ranging from the difficulty on the operative field isolation to the extension of the cavities to be restored, which may also have influenced on the longevity of the restorations. Although there is a possible bias related to the presence or absence of parafunctional habits, which were reported by the patients themselves, we suggest that studies with a methodology focused on the diagnosis of habits are necessary to evaluate their influence on fractures of CR restorations.

\section{References}

Almutairi, A. F., Albesher, N., Aljohani, M., Alsinanni, M., Turkistani, O., \& Salam, M. (2021). Association of oral parafunctional habits with anxiety and the Big-Five Personality Traits in the Saudi adult population. Saudi Dental Journal, 33(2), 90-98. https://doi.org/10.1016/j.sdentj.2020.01.003

Alves-rezende, M. C. R., Soares, B. M. S., Silva, J. S., Goiato, M. C., Túrcio, K. H. L., Zuim, P. R. J., \& Alves Claro, A. P. R. (2009). Frequency of parafunctional habits. Cross-sectional study in dental students. Revista Odontológica de Araçatuba, 30(1), 59-62.

Bakke, M. (2006). Bite Force and Occlusion. Seminars in Orthodontics, 12(2), 120-126. https://doi.org/10.1053/j.sodo.2006.01.005

Black, G. V. (1908). Operative Dentistry. Medico Dental.

Bortolleto, P. P. B., Moreira, A. P. S. M., \& Madureira, P. R. (2013). Análise dos hábitos parafuncionais e associação com Disfunção das Articulações Temporomandibulares. Revista Da Associacao Paulista de Cirurgioes Dentistas, 67(3), 216-221.

Cavalcante, J. G. de S., Araujo, H. T., Santos, N. E. B. dos, Silva, T. R. G., Santos, S. C. A. V. dos, Leitão, A. K. A., Picanço, P. R. B., \& Feitosa, V. P. (2020). Correlation between parafunctional habits and temporomandibular dysfunction: systematic review. Brazilian Journal of Development, 6(12), 103664103673. https://doi.org/10.34117/bjdv6n12-753

Demarco, F. F., Corrêa, M. B., Cenci, M. S., Moraes, R. R., \& Opdam, N. J. M. (2012). Longevity of posterior composite restorations: not only a matter of materials. Dental Materials, 28(1), 87-101. https://doi.org/10.1016/j.dental.2011.09.003

Demarco, F. F., Collares, K., Coelho-De-Souza, F. H., Correa, M. B., Cenci, M. S., Moraes, R. R., \& Opdam, N. J. (2015). Anterior composite restorations: A systematic review on long-term survival and reasons for failure. Dental Materials, 31(10), 1214-1224. https://doi.org/10.1016/j.dental.2015.07.005

Demarco, F. F., Collares, K., Correa, M. B., Cenci, M. S., Moraes, R. R., \& Opdam, N. J. (2017). Should my composite restorations last forever? Why are they failing? Brazilian Oral Research, 31, 92-99. https://doi.org/10.1590/1807-3107BOR-2017.vol31.0056

Friedman Rubin, P., Erez, A., Peretz, B., Birenboim-Wilensky, R., \& Winocur, E. (2017). Prevalence of bruxism and temporomandibular disorders among orphans in southeast Uganda: A gender and age comparison. Cranio - Journal of Craniomandibular Practice, 36(4), 243-249. https://doi.org/10.1080/08869634.2017.1331784

Gavish, A., Halachmi, E., Winocur, E., \& Gazit, E. (2000). Oral habits and their association with signs and symptoms of temporomandibular disorders in adolescent girls. Journal of Oral Rehabilitation, 27(1), 22-32. https://doi.org/10.1046/j.1365-2842.2000.00484.x 
Research, Society and Development, v. 10, n. 9, e48410918087, 2021

(CC BY 4.0) | ISSN 2525-3409 | DOI: http://dx.doi.org/10.33448/rsd-v10i9.18087

Hamburger, J. T., Opdam, N. J. M., Bronkhorst, E. M., \& Huysmans, M. C. D. N. J. M. (2014). Indirect restorations for severe tooth wear: fracture risk and layer thickness. Journal of Dentistry, 42(4), 413-418. https://doi.org/10.1016/j.jdent.2013.10.003

Heymann, H. O., Sturdevant, J. R., Bayne, S., Wilder, A. D., Sluder, T. B., \& Brunson, W. D. (1991). Examining tooth flexure effects on cervical restorations: a two-year clinical study. The Journal of the American Dental Association, 122(6), 41-47. https://doi.org/10.1016/s0002-8177(91)25015-1

Ichim, I., Li, Q., Loughran, J., Swain, M. V., \& Kieser, J. (2007). Restoration of non-carious cervical lesions. Part I. Modelling of restorative fracture. Dental Materials, 23(12), 1553-1561. https://doi.org/10.1016/j.dental.2007.02.003

Laske, M., Opdam, N. J. M., Bronkhorst, E. M., Braspenning, J. C. C., \& Huysmans, M. C. D. N. J. M. (2019). Risk Factors for Dental Restoration Survival: A Practice-Based Study. Journal of Dental Research, 98(4), 414-422. https://doi.org/10.1177/0022034519827566

Macfarlane, T. V., Blinkhorn, A. S., Davies, R. M., \& Worthington, H. V. (2003). Association between local mechanical factors and orofacial pain: Survey in the community. Journal of Dentistry, 31(8), 535-542. https://doi.org/10.1016/S0300-5712(03)00108-8

Melchior, M. de O., Mazzetto, M. O., \& de Felício, C. M. (2012). Temporomandibular disorders and parafunctional oral habits: An anamnestic study. Dental Press Journal of Orthodontics, 17(2), 83-89. https://doi.org/10.1590/S2176-94512012000200016

Namgung, C., Rho, Y. J., Jin, B. H., Lim, B. S., \& Cho, B. H. (2013). A retrospective clinical study of cervical restorations: Longevity and failure-prognostic variables. Operative Dentistry, 38(4), 376-385. https://doi.org/10.2341/11-416-C

Opdam, N. J. M., Van De Sande, F. H., Bronkhorst, E., Cenci, M. S., Bottenberg, P., Pallesen, U., Gaengler, P., Lindberg, A., Huysmans, M. C. D. N. J. M., \& Van Dijken, J. W. (2014). Longevity of posterior composite restorations: A systematic review and meta-analysis. Journal of Dental Research, 93(10), 943949. https://doi.org/10.1177/0022034514544217

Pedrini, D., Sonoda, C. K., Poi, W. R., Panzarini, S. R., Castro, J. C. M., \& Brandini, D. A. (2009). Razões para substituição de restaurações em clínica integrada. Pesquisa Brasileira Em Odontopediatria e Clinica Integrada, 9(2), 211-215. https://doi.org/10.4034/1519.0501.2009.0092.0013

Ribeiro, M. D. F., \& Pazinatto, F. B. (2016). Critérios clínicos para decisão entre substituição ou reparo de restaurações em resina composta - revisão de literatura. 73(3), 223. https://doi.org/10.18363/rbo.v73n3.p.223

Smales, R. J., \& Berekally, T. L. (2007). Long-term survival of direct and indirect restorations placed for the treatment of advanced tooth wear. The European Journal of Prosthodontics and Restorative Dentistry, 15(1), 2-6.

van Dijken, J. W. V., \& Pallesen, U. (2010). Fracture frequency and longevity of fractured resin composite, polyacid-modified resin composite, and resinmodified glass ionomer cement class IV restorations: An up to 14 years of follow-up. Clinical Oral Investigations, 14(2), 217-222. https://doi.org/10.1007/s00784-009-0287-z

Winocur, E., Littner, D., Adams, I., \& Gavish, A. (2006). Oral habits and their association with signs and symptoms of temporomandibular disorders in adolescents: a gender comparison. Oral Surgery, Oral Medicine, Oral Pathology, Oral Radiology and Endodontology, 102(4), 482-487. https://doi.org/10.1016/j.tripleo.2005.11.007 